\title{
LUT
}

University

\section{Reducing and Reinvesting Working Capital in Business Ecosystems}

\author{
Rissanen Matti, Pirttilä Miia, Lind Lotta, Kärri Timo
}

This is a Author's accepted manuscript (AAM) version of a publication

published by Springer, Cham

in Liyanage J., Amadi-Echendu J., Mathew J. (eds) Engineering Assets and Public Infrastructures in the Age of Digitalization. Lecture Notes in Mechanical Engineering.

DOI: 10.1007/978-3-030-48021-9_22

Copyright of the original publication: (C) Springer Nature

Please cite the publication as follows:

Rissanen, M., Pirttilä, M., Lind, L., Kärri, T. (2020). Reducing and Reinvesting Working Capital in Business Ecosystems. In: Liyanage J., Amadi-Echendu J., Mathew J. (eds) Engineering Assets and Public Infrastructures in the Age of Digitalization. Lecture Notes in Mechanical Engineering. Springer, Cham. DOI: 10.1007/978-3-030-48021-9_22

This is a parallel published version of an original publication. This version can differ from the original published article. 


\title{
Reducing and Reinvesting Working Capital in Business Ecosystems
}

\author{
Matti Rissanen ${ }^{1}$, Miia Pirttilä ${ }^{1}$, Lotta Lind ${ }^{1}$, Timo Kärri ${ }^{1}$
}

\begin{abstract}
Issues related to supply chain finance, also known as supplier finance or reverse factoring, have been in focus of both academics and practitioners after the financial crisis. In the broadest perspective of supply chain finance, it concerns all supply chain objects: the flow of goods, information and finance; processes; current and fixed assets; and personnel involved in the supply chain. This way, supply chain finance connects with the assets management of business ecosystems. The focus of schemes in this area is to support the working capital management of the key suppliers of the buyer. The schemes are implemented between the tier 1 supplier and the buyer. In this paper, we study working capital management in an information and communications technology business ecosystem producing desktop computers, spreading the study from the focal actor to the component suppliers in the furthest tier. We show the potential that exists to release capital from operational issues to more profitable purposes.
\end{abstract}

Keywords: working capital management, business ecosystem, supply chain finance, ICT industry

\section{Introduction}

Williamson (1985) categorizes assets besides fixed and variable parts further based on the degree of specificity, wholly specific and nonspecific. Most of the previous asset management literature discuss the specific fixed assets like site specify, physical assets specify or human assets specificity. Our interest direct to specific variable (current) assets that can be considered including dedicated assets in Williamson classification i.e. inventories, accounts receivable and accounts payable. Asset items accounts receivable and payable are highly specific, the products or services are sold to specific buyers. The amount of bill is in accounts receivable for

M. Rissanen ( $\bowtie)$, e-mail: matti.rissanen@lut.fi

M. Pirttilä, e-mail: miia.pirttila@lut.fi

L. Lind, e-mail: lotta.lind@lut.fi

T. Kärri, e-mail: timo.karri@lut.fi

${ }^{1}$ Lappeenranta University of Technology, Industrial Engineering and Management, Finland 
the supplier of products or services and the same amount is registered to a buyer's accounts payable.

The flow of financial resources in supply chains gained attention during recent years (Hoffman \& Kotzab, 2010; Wuttke et al., 2013; Gelsomino et al., 2016). The financial crisis of 2008 acted as a beginning for scholars to study and companies to manage the financial flow in addition to the material flow of a supply chain (Seifert \& Seifert, 2008). Large or otherwise powerful companies took advantage of delaying payments to their suppliers in order to improve their working capital management i.e. the greater proportion of assets is financed by suppliers than before the financial crisis. The first tier suppliers of these large companies passed the problem forward to their suppliers, enforcing them to extend payment terms and so the effect continued further upstream. The government of the United Kingdom solved the liquidity problem of small and medium sized suppliers by introducing a reverse factoring program in order to finance the supply chains (Seifert \& Seifert, 2008). This program offers early payments to British suppliers at a cost based on buyers' credit rating and the powerful buyer can implement strategy that in other context would be squeezing suppliers. To protect European business, the European Union introduced a late payment directive that aim to limit payments to supplier max 60 days.

Business ecosystems are characterized by supplementary functions between individual companies and coevolution in a direction set by the focal actor (Moore 1998; Adner, 2016). The companies are drawn together through a platform (a technology, tool or service) provided by the focal actor for the ecosystem partners to use to improve their own performance as well as the performance of the ecosystem (Iansiti \& Levien, 2004). Members of the ecosystem should jointly participate in the development of the platform to improve the competitiveness of their customers. Information and communications technology (ICT) ecosystems and industry as whole are renowned for requiring continuous innovation and increasing production capacity. For this reason, ICT companies collaborating should think of their networked environment as an ecosystem consisting of multilateral relationships rather than a traditional supply chain mainly consisting of bilateral relationships. An example case of a failed ICT ecosystem is IBM (see Iansiti \& Levien 2004), who limited innovation and extracted value from its partners only to fail when more open strategies were offered by companies like Microsoft and Apple.

The relationships within a supply chain can be broken into dyadic ones whereas the relationships in business ecosystems are multilateral (Adner, 2016). The positions of different companies in supply chains are divided into upstream (supplier) and downstream (buyer) (ibid.) but in business ecosystems, the multilateral relationships have to be described in other manners. In fact, the positions and boundaries of an ecosystem are impossible to precisely define since it can take part in multiple industries but rather the ecosystem should be described by recognizing the 
organizations that are the most critical to the business of the focal actor (Iansiti \& Levien, 2004).

In a global context, ensuring the health of a supply chain from a financial point of view by directives and programs may not be a sustainable solution - instead, it rather hides and shifts the original problem without solving it. In this paper, we study the working capital management of a global ICT ecosystem with Dell as its focal actor. We demonstrate the potential to release capital by improving the cycle time of working capital. The demand for semiconductor products and other electronics increase through the rise of Internet of Things and other technological advances. To meet this demand companies in ICT sector have to continuously innovate and invest in new plants and decrease the risk of disturbances in business ecosystem to ensure production. The aim of this paper is to demonstrate through an example of how companies operating collaboratively in a business ecosystem by using working capital management can reduce tied up capital. In addition, we introduce some possibilities on how to reinvest the capital in more profitable targets.

\section{Research design}

The focus of this study is on a business ecosystem in ICT industry. Dell was selected as the focal actor for the ecosystem to be studied, because Dell operates on negative cycle time of operating working capital (Bruun \& Mefford 2004; Hofmann \& Kotzab 2010; Lind et al. 2016). This indicates that the suppliers and buyers of Dell favour it by offering long payment time and paying fast. Dell has no need to arrange the finance of its specific current assets under study. We started the research process by positioning the suppliers listed by Dell (Dell, 2018) to the ecosystem (Figure 1). The companies, who had data available and were included in the study, are presented in solid colour. In addition to using the supplier list of Dell, some companies were added to the ecosystem to ensure that with the ecosystem companies we would be able to build a working desktop computer. The ecosystem presented in Figure 1 is by no means a full representation of Dell's ecosystem but rather a part of it, which can produce a desktop computer. In addition, we dismantled a display with Dell's brand to find more about the suppliers, since the list Dell provides does not go much into detail on what each company supplies. Some potential relationships are presented in Figure 1 as lines between the companies. The nature of these links is not in the scope of this study but they could include transfer of materials, information, influence and funds (Adner, 2016).

In the ecosystem, the suppliers are set in four tiers based on the importance of the supplier in providing the desktop computer. In the first tier are companies that provide the computational technology: chipset, motherboard, central processing unit and graphical processing unit. Intel stands out in this tier for being a key partner to Dell as well as well as providing most of the chipsets used in Micro-Star International's (MSI) motherboards. MSI also acts as an original design manufacturer for 
Dell. Adding computer parts delivered by companies in the second tier, we have all the parts necessary in the computer case (power supply unit, memory, storage, cooling). Third tier includes the providers of peripheral devices (keyboard, mouse, display) and parts for supplementary functionalities (audio card, network card, optical drive). Fourth tier consists of companies that provide components and/or manufacturing for all the previous tiers.

Finally, the research sample presents Dell's business ecosystem within ICT industry including figures from 20 companies for each year in the $2014-2016$ period. The used methodology can be described as archival research (Moers, 2007). Data for the study was collected from public sources and Thomson ONE database. Public sources being financial statements and annual reports published by the studied companies. Due to the fact that some of the public sources used languages the authors could not reliably translate, some data was collected from the Thomson ONE database.

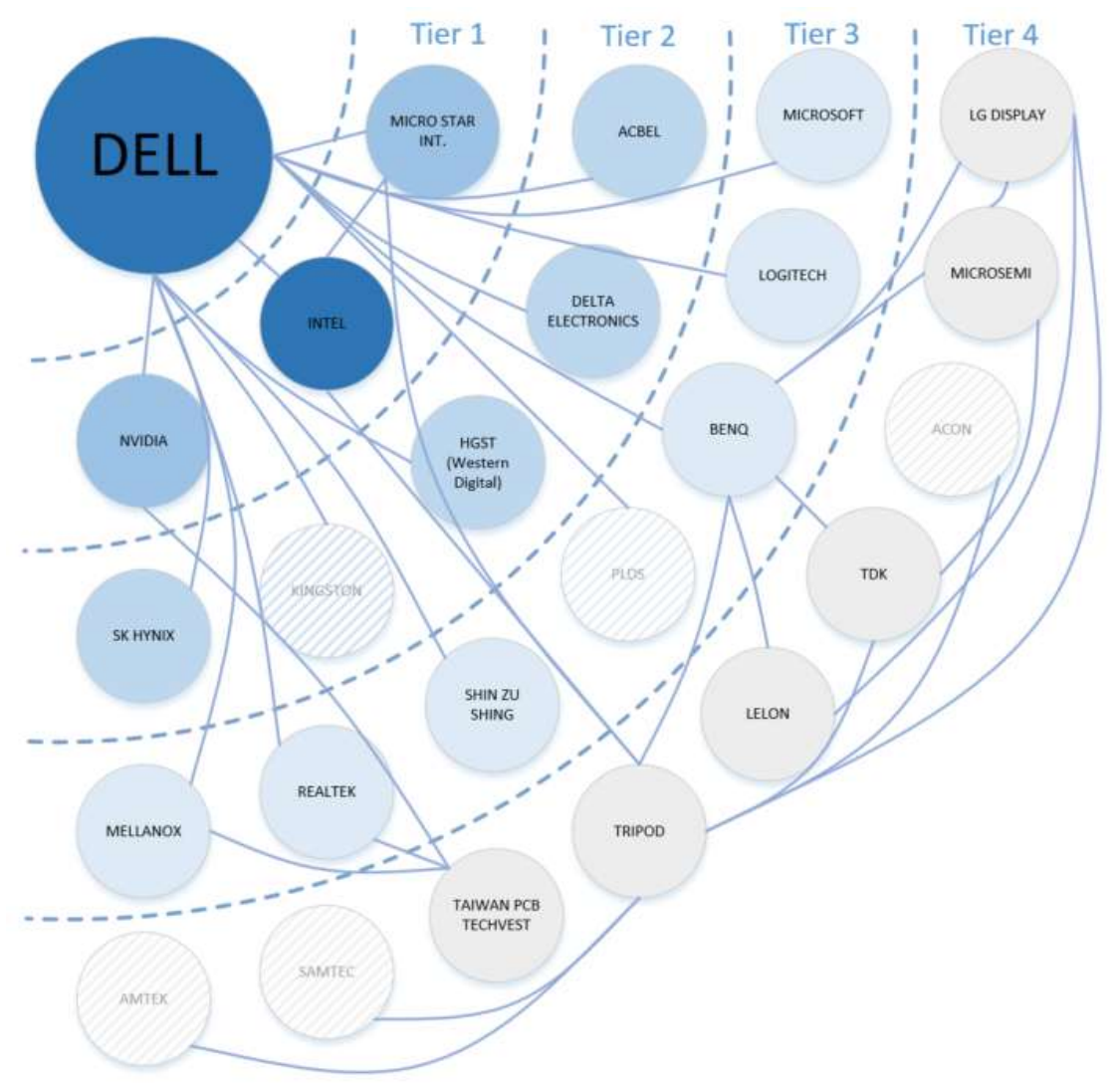

Figure 1 Structure of the present study ecosystem with the companies of sample 
The working capital management in the ecosystem is studied by the cash conversion cycle (CCC) developed by Richards and Laughlin (1980). The CCC consists of three components: cycle times of inventories (DIO), accounts receivable (DSO) and accounts payable (DPO). Relative profitability is measured by the return on total assets $(\mathrm{ROA} \%)$. The definitions and calculations for each measure are shown in Table 1.

Table 1 Measurement methods of working capital management and profitability

\begin{tabular}{lll}
$\begin{array}{l}\text { Variable } \\
\text { DIO }\end{array}$ & $\begin{array}{l}\text { Description } \\
\text { Cycle time of inventories }\end{array}$ & $\begin{array}{l}\text { Definition } \\
\text { (Inventories/Sales)*365 }\end{array}$ \\
\hline DSO & Cycle time of accounts receivable & (Accounts receivable/Sales)*365 \\
\hline DPO & Cycle time of accounts payable & (Accounts payable/Sales)*365 \\
\hline CCC & Cash conversion cycle & CCC = DIO + DSO - DPO \\
\hline ROA & Return on total assets & $\begin{array}{l}\text { Earnings before interest and taxes } \\
\text { /Total assets }\end{array}$ \\
\hline
\end{tabular}

\section{Results and analysis}

To analyse the state of working capital management in Dell's ecosystem we calculated the CCC and its components for each year from 2014 to 2016. The return on assets indicates the profitability of the ecosystem. Figures are presented in Table 2 for each company included in the sample and for the four tiers they are placed in.

The results of CCC calculations reveal that the companies in fourth tier tie up more working capital in comparison to the other tiers. We identified two specific working capital strategies applied by companies in the ecosystem. Dell, the largest direct seller of PCs in the world, has achieved negative CCC by maintaining long payment terms with its suppliers. Besides Dell, four other companies (* in Table 2) in the sample collect the payments of their customer faster than they pay for their suppliers, in other words, their DPO is longer than their DSO. It can be assumed that this is their strategy for managing trade credit. Suppliers finance the purchases of their buyers by offering generous payment terms. The second strategy is for companies to use supply chain finance as a means to finance their inventories, i.e. their DPO is longer than the DIO ( $\propto$ in Table 2). Thirteen companies of the sample have managed to negotiate favourable payment terms from this point of view so it can be considered a popular strategy, for suppliers to be financing the inventories of buyers, in this ecosystem. Those four companies that postpone payments to their suppliers can finance part of their inventories using supplier finance, and Dell does not have to tie up any money to finance its operational working capital. After this analysis, we have seven companies left that did not apply either of the two working capital management strategies. These companies pay their suppliers relatively fast. They favour their customers offering relative long payment periods and their cycle time of inventory varies from a month to two months. Those whose DIOs are long, the work in process ties up relatively much working capital. 
Table 2 The average figures of CCC and its components and ROA of the years 2014-2016

\begin{tabular}{|c|c|c|c|c|c|}
\hline The name of company & DIO & DSO & DPO & $\mathrm{CCC}$ & ROA \\
\hline DELL * $\not$ & 13 & 45 & 89 & -30 & $-2 \%$ \\
\hline TIER 1 & 43 & 45 & 35 & 53 & $13 \%$ \\
\hline INTEL & 32 & 47 & 16 & 63 & $21 \%$ \\
\hline MICRO STAR INTERNATIONAL $*$ a & 63 & 52 & 66 & 49 & $9 \%$ \\
\hline NVIDIA & 34 & 37 & 24 & 47 & $9 \%$ \\
\hline TIER 2 & 43 & 69 & 52 & 60 & $9 \%$ \\
\hline ACBEL $\alpha$ & 45 & 87 & 81 & 51 & $4 \%$ \\
\hline DELTA ELECTRONICS $\not$ & 43 & 84 & 64 & 62 & $9 \%$ \\
\hline HGST (WESTERN DIGITAL) $*$ a & 46 & 39 & 47 & 38 & $6 \%$ \\
\hline SK HYNIX & 37 & 67 & 16 & 88 & $16 \%$ \\
\hline TIER 3 & 35 & 74 & 48 & 60 & $12 \%$ \\
\hline BENQ a & 46 & 89 & 78 & 57 & $2 \%$ \\
\hline LOGITECH $*$ Q & 42 & 29 & 46 & 26 & $5 \%$ \\
\hline MELLANOX & 33 & 53 & 27 & 58 & $37 \%$ \\
\hline MICROSOFT $a$ & 11 & 77 & 29 & 59 & $12 \%$ \\
\hline REALTEK $*$ a & 42 & 44 & 50 & 36 & $6 \%$ \\
\hline SHIN ZU SHING a & 35 & 149 & 57 & 127 & $10 \%$ \\
\hline TIER 4 & 44 & 90 & 41 & 93 & $5 \%$ \\
\hline LELON & 55 & 122 & 27 & 150 & $8 \%$ \\
\hline LG DISPLAY $a$ & 33 & 56 & 41 & 49 & $1 \%$ \\
\hline MICROSEMI & 60 & 57 & 24 & 92 & $3 \%$ \\
\hline TAIWAN PCB TECHVEST $\propto$ & 32 & 125 & 69 & 87 & $6 \%$ \\
\hline TDK & 50 & 77 & 43 & 84 & $8 \%$ \\
\hline TRIPOD $a$ & 37 & 103 & 44 & 96 & $5 \%$ \\
\hline
\end{tabular}

To analyse how much money is tied up in this ecosystem, we analyse the figures of Dell and the four tiers in Dell's ecosystem. The amounts are presented in millions of USD. FED's rates were used for those companies whose figures were in other currencies than USD. The scenario is formed as follows: for each company, the shortest cycle time of each CCC component in their tier was selected as a new cycle time. In the calculations, it was assumed that this shortening of the DIO, DSO and DPO did not affect the sales revenue or EBIT of companies. Calculations with the new cycle times were done for each year of the observation period. The scenario can be considered too general because it does not consider the specific characterises of companies. Our aim is to demonstrate the possibilities of the business ecosystem have to reduce its tied up working capital hence how a company would do that is not at scope. The new value of a working capital item (inventories, accounts receivable and payable) was calculated as following: 


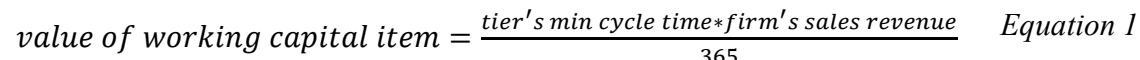

This scenario leads to an ecosystem where buyers pay their bills fast to their suppliers and they can in favour give their own customers a rise in payment time from 26 days to 54 in 2016. Cycle time of inventories in each tier varies from 10 days to 43 days in 2016. The value of each working capital item and total assets is presented as the sum of the tier and ROA\% is the average of the tier. Shortening the cycle time of working capital components, like set in the scenario, decreases the capital tied up in the ecosystem from three to six percent: 2016: 12 415; 2015: 11808 and 2014: 16832 millions USD. The ROA\% does not increase remarkable because the total amount of assets are huge in comparison with operational working capital. The improvement of ROA $\%$ can be achieved by reinvesting releasing capital to a more profitable target. The scenario means an increase of $1.07 \%, 3.56 \%$, $14.48 \%$ and $14.35 \%$ in ROA in tiers 1 to 4 respectively. In Table 3 we present more detailed figures using the year 2016 as an example. The results of scenario suggest that the business ecosystem could release 12 Milliard USD from operational working capital to be reinvested to targets that support the business ecosystem's goal.

Table 3 Actual figures of the ecosystem and results of the scenario in millions of USD, the year 2016

\begin{tabular}{|c|c|c|c|c|c|c|c|}
\hline & & $\begin{array}{r}\text { inven- } \\
\text { tory }\end{array}$ & $\begin{array}{r}\text { accounts } \\
\text { receivable }\end{array}$ & $\begin{array}{r}\text { accounts } \\
\text { payable }\end{array}$ & $\begin{array}{r}\text { working } \\
\text { capital }\end{array}$ & $\begin{array}{r}\text { total } \\
\text { assets } \\
\end{array}$ & ROA \% \\
\hline \multirow{6}{*}{ 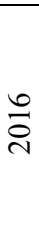 } & Dell & 2538 & 9420 & 14422 & -2464 & 118206 & $-2.8 \%$ \\
\hline & Tier 1 & 6481 & 6254 & 3328 & 9407 & 122255 & $13.9 \%$ \\
\hline & Tier 2 & 4900 & 6288 & 4025 & 7163 & 64364 & $7.4 \%$ \\
\hline & Tier 3 & 2760 & 18873 & 7468 & 14164 & 199002 & $11.5 \%$ \\
\hline & Tier 4 & 3673 & 7227 & 4333 & 6566 & 42426 & $5.4 \%$ \\
\hline & BEC Total & 20352 & 48061 & 33577 & 34837 & 546253 & \\
\hline
\end{tabular}

\begin{tabular}{|c|c|c|c|c|c|c|c|}
\hline \multirow{6}{*}{ 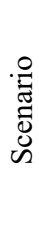 } & Dell & 2538 & 9420 & 14422 & -2464 & 118206 & $-2.8 \%$ \\
\hline & Tier 1 & 5637 & 6046 & 2816 & 8868 & 121715 & $13.9 \%$ \\
\hline & Tier 2 & 4789 & 4203 & 1645 & 7347 & 64548 & $7.5 \%$ \\
\hline & Tier 3 & 2376 & 6371 & 6252 & 2495 & 187333 & $12.6 \%$ \\
\hline & Tier 4 & 3171 & 5567 & 2561 & 6177 & 42036 & $6.1 \%$ \\
\hline & BEC Total & 18511 & 31607 & 27696 & 22422 & 533838 & \\
\hline
\end{tabular}




\section{Discussion and conclusions}

This paper studied working capital management in the business ecosystem formed around a focal company in the ICT industry. The operational working capital is considered as a dedicated asset in this study. The analysis confirmed the findings of previous studies, which have shown that with the help of its business partners, Dell is able to maintain payment terms that enable operating with negative working capital (Bruun \& Mefford 2004; Hofmann \& Kotzab 2010; Lind et al. 2016). The scenario conducted in the paper showed that the business ecosystem could release working capital by better collaboration. Benchmarking the cycle times within the tiers and taking the best practices into use could be a way to reduce working capital. Of course, in reality, such scenario would be difficult to realize and would not end up in win-win situations for every actor, but from the perspective of a business ecosystem, it would result in more effective financial flows.

In terms of working capital management, Dell is a very strong player in the ecosystem. The results indicate that its success is enabled by the other partners in the ecosystem. Judging by the customisability of Dell's desktop computer products, they do not limit the innovation of their ecosystem partners in the way that lead IBM's similar ecosystem to fail. The whole ICT industry thrives on innovation and apparently, that is a good enough platform for Dell's ecosystem to succeed. However, Dell has strong competitors and a strong innovative platform from one of them could quickly weaken Dell's position in its own ecosystem.

In recent years, academic research on working capital management has concentrated on different solutions of supply chain finance, including financial institutions, with the aim of ensuring the sufficient financial flows between the different actors in the ecosystem. However, collaboration in working capital management at the ecosystem level could also be conducted through negotiations. Instead of feeding banks with the interest costs and service fees of supply chain solutions, ecosystems could collaborate in order to release excess working capital which is unproductively tied up in the payment terms and inventories, and use it for example to strategic investments which would benefit the whole ecosystem long term.

\section{Acknowledgements}

The authors would like to thank the Finnish Cultural Foundation for the financial support of Miia Pirttilä.

\section{References}

Adner, R. 2016. 'Ecosystem as structure: an actionable construct for strategy', Journal of Management, Vol. 43, (1), pp. 39-58. 
Bruun, P. and Mefford, R.N. 2004. 'Lean production and the Internet', International Journal of Production Economics Vol. 89, (3), pp. 247-260.

Dell. 2018. Supply Chain. [Online] Accessed: 4.4.2018 Available at: http://www.dell.com/learn/us/en/uscorp1/cr-social-responsibility?s=corp

Gelsomino, L.M., Mangiaracina, R., Perego, A. and Tumino, A. 2016. 'Supply chain finance: a literature review', International Journal of Physical Distribution \& Logistics Management, Vol. 46, (4), pp. 348-366.

Hofmann, E. and Kotzab, H. 2010. 'A supply chain-oriented approach of working capital management', Journal of Business Logistics, Vol. 31, (2), pp. 305-330.

Iansiti, M., and Levien, R. 2004. 'Strategy as ecology', Harvard Business Review, Vol. 82, (3), pp. 68-81.

Lind, L., Monto, S., Kärri, T. and Schupp, F. 2016. 'Detecting working capital models in the ICT supply chains'. International Journal of Supply Chain and Inventory Management, Vol. 1, (3), pp. 233-249.

Moers, F. 2007. 'Doing archival research in management accounting'. In: Chapman S.C., Hopwood, A.G., Shields, M.D. (Eds.). Handbook of Management Accounting Research, Vol. 1, Elsevier, The Netherlands, pp. 399-413.

Moore, J. F. 1998. 'The rise of a new corporate form', Washington Quarterly, Vol. 21, (1), pp. 167-181.

Richards, V.D. and Laughlin, E.J. 1980. ‘A Cash Conversion Cycle Approach to Liquidity Analysis’, Financial Management, Vol. 9, (1), pp. 32-38.

Seifert, R.W. and Seifert, D. 2008. 'Working Capital in Times of Financial Crisis: Three Trade Credit Strategies', Perspectives for managers, No. 166, 4 p.

Williamson, O. E. (1985), The Economic Institutions of Capitalism, Free Press, New York.

Wuttke, D.A., Blome, C. and Henke, M. 2013. 'Focusing the financial flow of supply chains: an empirical investigation of financial supply chain management', International Journal of Production Economics, Vol. 145, (2), pp. 773-789. 